\title{
ŠKOLY PODPORUJÍCÍ ZDRAVÍ
}

8: $200-435,2006$

ISSN $1212-4117$

\author{
Kvetoslava Kotrbová 1,2,3, Markéta Kastnerová1,2, Vladimír Vurm ${ }^{1}$ \\ ${ }^{1}$ Jihočeská univerzita $\mathrm{v}$ Českých Budějovicích, Zdravotně sociální fakulta, katedra veřejného \\ a sociálního zdravotnictví \\ ${ }^{2}$ Krajská hygienická stanice Jihočeského kraje se sídlem v Českých Budějovicích \\ ${ }^{3}$ Kontaktní a doléčovací centrum pro drogovou závislost, o. s., Háječek, České Budějovice
}

\section{ÚVOD}

Jedním ze stále naléhavějších trendů vývoje společnosti ve 21. století je zhoršující se stav zdraví lidí - od nejmladších po nejstarší - na celém světě. Na jeho zdolání se ve světě od roku 1986 postupně vytvárí zcela nová strategie $\mathrm{v}$ podobě celoživotní podpory zdraví, jejíž složkou je výchova jedince $\mathrm{k}$ odpovědnosti za zdraví. Proces podpory zdraví ve školách se realizuje některými programy, z nichž největší popularitě se těší a efektivitu svých výsledků dlouhodobě potvrzuje evropský program Škola podporující zdraví (ŠPZ). Posláním programu je dosáhnout, aby každé dítě v ČR mělo možnost být vzděláváno ve škole, která veškerou svou činností podporuje zdraví. Program ŠPZ byl prvním programem v ČR, který po roce 1989 prrinesl ucelený pohled na postupnou změnu pojetí existující školy, vzdělávání a pedagogiky z hlediska očekávaných perspektiv a trendů společensko-politického vývoje, mezi něž patří strategie podpory zdraví obyvatelstva. Je proto koncipován jako dlouhodobý program pro každou školu $\mathrm{v}$ hlavním proudu vzdělávání, která se chce $\mathrm{v}$ souladu $\mathrm{s}$ nimi rozvijet. Tímto svým zaměřením program podpory zdraví ve škole od svého začátku aktivně přispívá $\mathrm{k}$ procesu zkvalitňování českého školství jako celku. Záměrem programu ŠPZ je aplikovat strategii podpory zdraví na podmínky školy a prispět $\mathrm{k}$ její účasti na vlastní proměně a rozvoji. V praxi školy to znamená, že všechno, co se ve škole dělá záměrně (vyučované kurikulum, školou organizované činnosti), a rovněž všechno, co se v ní děje živelně (skryté kurikulum, kultura a ethos školy), se pedagogové učí promýšlet a ovlivňovat pod zorným úhlem obou pólů možných důsledků, jaké má působení školy na zdraví svých lidí - žáků, pedagogů, zaměstnanců, rodičů, spoluobčanů $\mathrm{v}$ obci - důsledků pozitivních (protektivních, podporujících zdravî) a negativních (rizikových, ohrožujících zdravî).

Svým zaměřením na podporu zdraví člověka (ve všech jeho aspektech, u všech aktérů a ve všech složkách prostředî) poskytuje program jak eticky, tak vědecky zdůvodněný nový rozměr pro plánování, provádění i posuzování činnosti školy, který ve svém důsledku vypovídá o její kvalitě (Havlínová, Herotová, Vildová, 2003).

\section{VÝVOJ PROJEKTU ŠKOLA PODPORUJÍCÍ ZDRAVÍ (ZDRAVÁ ŠKOLA)}

Sít' škol podporujících zdraví začala vznikat v evropských zemích od r. 1990. Je garantována třemi mezivládními nadnárodními organizacemi: Světovou zdravotnickou organizací pro Evropu (WHO EURO v Kodani), Radou Evropy (CE) a Komisí Evropské unie (CEU). Česká republika vstoupila do sítě v letech 1992 - 93 společně s 94 školami, z nichž 11 mělo plnit úkol pilotních škol podporujících zdraví. Zájem o projekt byl obrovský. Sít' však musela po druhém výběrovém kole (r. 1993) zůstat uzavřena, aby se mohly zejména pilotní školy intenzivně rozvíjet a ověřovat životnost projektu. Vzhledem $\mathrm{k}$ tomu, že životnost projektu se na evropské i naší úrovni prokázala, je v ČR od r. 1999 otevřena pro další zájemce. V roce 1994 u nás vznikl nový impulz, který významně rozšíríil podporu zdraví do další oblasti školství, do sítě mateřských škol. Byla založena sít' mateřských škol podporujících zdraví. V současné době tvoří sít' ŚPZ zhruba dvě stě škol základních a mateřských, které se vzdělávají, evaluují a inovují svoje školní projekty. Sít' je trvale otevřena novým zájemcům. Národní program ŠPZ je v domácích poměrech i v evropské síti hodnocen jako efektivně vedená aktivita podpory zdraví (Havlínová, Vildová, 1999, s. 33). Vliv programu ŠPZ na žáky a učitele se projevuje pozitivními změnami sociálního prostředí ve škole, od- 
povědnějším způsobem chování ke zdraví a novými dovednostmi $\mathrm{v}$ zacházení se zdravotními riziky. Finanční zdroje pro činnosti spojené s realizací programu ŠPZ jsou získávány částečně $z$ účelově vázaných prostředků $\mathrm{SZO}$ a částečně $z$ nabídky dotačních programů, především dotačního programu Ministerstva zdravotnictví ČR Národní program zdraví - Projekty podpory zdraví. $\mathrm{V}$ rámci daných možností byly dosaženy první výsledky $\mathrm{v}$ oboustranné spolupráci resortu zdravotnictví a MŠMT a jeho institucemi na konkrétních úkolech. Posláním programu ŠPZ je dosáhnout, aby každé dítě v C CR mělo možnost být vzděláváno ve škole, která svou činností podporuje zdraví. Program
ŠPZ pomáhá školám (MŠ a ZŠ), aby si týmovou spoluprací stanovily dlouhodobou a vyváženou koncepci, strategii a metody řízení své kvalitativní proměny $\mathrm{v}$ dílnu zdravého způsobu života a práce. Cílem proměny je trvale umožňovat optimální vývoj a rozvoj každého jednotlivce, žáka a učitele, po stránce tělesné, duševní a sociální. Plněním takto salutogenně pojatého cíle je program současně nástrojem včasné primární prevence civilizačních chorob, antisociálního chování a všech závislostí (Kubrichtová et al., 2004, s. 102). Obrázková loga projektu zdravá škola, projektu zdravá mateřská škola a evropské sítě škol podporujících zdraví jsou zobrazena na obr. 1.

Obr. 1. Obrázková loga projektu zdravá škola, projektu zdravá mateřská škola a evropské sítě škol podporujících zdraví.

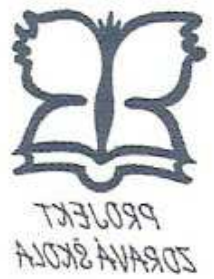

POJETÍ ZDRAVÍ A PODPORA ZDRAVÍ

Filozofie podpory zdraví vychází z vědeckých poznatků o tom, že zdraví každého jednotlivce (at' si to uvědomujeme, nebo ne) je výslednicí vzájemného působení všech stránek jeho bytosti a jeho vztahů k okolnímu světu. Bez uvědomování nezbytného vnitřního i vnějšího souladu není možné uchovat zdraví individuální ani zdraví světa. Zdraví člověka neznamená jen nepř́tomnost nemoci, zdraví je výslednicí vzájemných interakcí celého člověka, všech jeho systémů a složek na úrovni biologické, psychické, sociální, duchovní a enviromentální (holistické pojetí zdravî). Chránit a posilovat zdraví znamená pozitivně působit na všechny jeho složky. Důležitou roli přitom hraje životní styl jednotlivce i skupiny. Životní styl a chování, které zdraví podporují, je třeba vytvářet již $\mathrm{v}$ předškolním a školním věku dítěte, kdy se návyky a postoje upevňují nejtrvaleji. Nejsnáze se vytvářejí spontánně, prrímou zkušeností dítěte, tzn. tím, že dítě kolem sebe vidí př́klady zdravého chování, a také tím, že žije ve zdravě

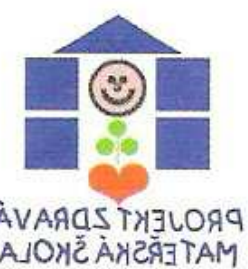

utvářených životních podmínkách. Nejvýznamnějšími aktéry procesu podpory zdraví jsou rodiče a pedagogové. Klíčovou institucí pro realizaci podpory zdraví je škola, kterou prochází celá populace žijící na zemi (Havlínová, Herotová, Vildová, 2003).

Škola, která se rozhodla podporovat zdraví, přistoupila na určitá filozofická hlediska a principy své činnosti. S podporou zdraví souvisí ve škole téměř všechno, co se v ní děje. Existují tři důvody pro tvrzení, že právě zdraví je tím činitelem, o němž si dovolujeme tvrdit, že prolíná celou činností školy. Prvním důvodem je, že zdraví je všeobecně uznávanou hodnotou. Druhým důvodem je, že současné pojetí zdraví klade důraz na souvislosti. Považuje celkové zdraví jedince za výslednici jeho zdraví tělesného, duševního, duchovního a sociálního a také za součást zdraví užší i širší komunity a přírody. Třetím důvodem je, že na zdraví člověka má vliv jeho chování a způsob života.

Interakční pojetí zdraví umožnilo vznik 
nové oblasti preventivních strategií, tzv. podpory zdraví. Podpora zdraví překročila hranice zdravotnictví, protože největší prostor pro své působení spatřjuje $\mathrm{v}$ komunitách, $\mathrm{v}$ nichž lidé prírozeně žijí nebo pracují. Proto také komunitní programy podpory zdraví musí vycházet nejen $\mathrm{z}$ poznatků, metod a technik lékařských oborů, ale také $z$ oborů psychologických, sociologických, pedagogických. Sdílet interakční pojetí zdraví znamená uplatňovat zřetel k vzájemné propojenosti složek zdraví ve třech interakčních soustavách: 1. individuální: zdraví je spojeno se všemi složkami bytosti jedince, kterou tvoří: organismus (tělesné zdravî), struktura psychických funkcí (duševní zdravî), osobnost (sociální a duchovní zdravî); 2. komunitní: zdraví jedince je propojeno se zdravím komunity, $v$ níž žije nebo pracuje; 3. globální: zdraví jedince, které je propojeno se zdravím jednotlivých společenství, $\mathrm{v}$ nichž jedinci žijí nebo pracují, je propojeno se zdravím světa (Havlínová et al., 1998, s. 275).

\section{OBSAH PROGRAMŮ PODPORA ZDRAVÍ VE}

\section{ŠKOLE}

Cílem programu výchova $\mathrm{k}$ podpoře zdraví ve škole podporující zdraví je rozvijet životní kompetence každého žáka tak, aby úcta ke zdraví a schopnost chovat se odpovědně ke zdraví svému i druhých patřily mezi jeho životní priority. Klíčové životní kompetence jsou formulovány na úroveň dospělého člověka (Havlínová, Herotová, Vildová, 2003). Žák si uvědomuje, že zdraví je prioritní hodnotou, má odpovědnost za vlastní chování a zpo̊sob života, posiluje duševní odolnost vůči stresům, negativním zážitkům a vlivům, dovede dělat správná rozhodnutí a volby, dovede řešit problémy a spolupodílí se na tvorbě podmínek a prostředí pro zdraví všech. Při hledání a uskutečňování konkrétních cest staví ŠPZ na dvou principech, které spojují a prolínají celou její činnost: 1 . na respektu $\mathrm{k}$ potřebám jednotlivce (žáka stejně jako učitele), počínaje potřebami biologickými, až po potřeby vyšší jako je seberealizace; 2 . na komunikaci a spolupráci uvnitř školy všech se všemi a mezi sebou (učitelů, žáků, rodičů) i vně školy (školy s obcí a dalšími partnery). Aby obsáhla podporu zdraví v celé své sféře, má ŠPZ tuto sféru definovanou třemi oblastmi, které se nazývají pilíře: prostředí a podmínky, učení, partnerství a spolupráce. Jsou stejné v základní škole jako v mateřské. Pro každý piliŕr jsou stanoveny určité zásady, jimiž se ŠPZ řídí ve své konkrétní činnosti. Program ŠPZ pro základní školu obsahuje 9 zásad, program ŠPZ pro mateřskou školu jich obsahuje 16. V jednotlivých zásadách se však již školy základní a mateřské liší. Zásadami se podařilo postihnout odlišnosti mezi oběma druhy škol a rozdíly dané věkem dětí.

Na obr. 2 je znázorněna struktura programu podpory zdraví. Škola podporující zdraví je taková, která tyto zásady aktivně naplňuje (Havlínová, Vildová, 1999, s. 33).

Obr. 2. Struktura programu podpory zdraví.

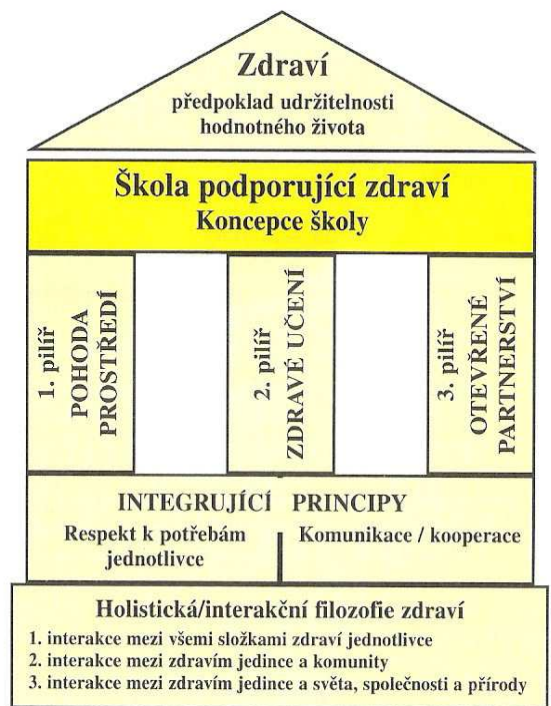




\section{ŠKOLA PODPORUJÍCÍ ZDRAVÍ (ŠPZ) SE ŘíDÍ TĚMITO ZÁSADAMI:}

\section{1. pilír: Pohoda prostředí \\ 1. zásada: Pohoda věcného prostředí}

ŠPZ se stará o všestrannou a vyváženou nabídku podmínek příznivých pro pohodu věcného prostředí tím, že se na jejich tvorbě a péči o ně podílejí všechny věkové skupiny.

2. zásada: Pohoda sociálního prostředí

Ve ŠPZ lidé usilují o to, aby jejich chování vyjadřovalo humanistické postoje jednoho k druhému: úctu, důvěru, snášenlivost; uznání, účast a empatii; otevřenost v komunikaci a vůli ke spolupráci a pomoci druhému.

\section{3. zásada: Pohoda organizačního prostředí}

SPZ uvádí organizaci činnosti ve škole do souladu s požadavky životosprávy žáků a učitelů, zvláště s ohledem na rytmicitu biologických funkcí (režim dne), výživu a pohybovou aktivitu.

\section{2. pilíř: Zdravé učení}

\section{4. zásada: Smysluplnost}

ŠPZ je propojená se skutečným životem. Dbá o praktickou využitelnost toho, co se děti ve škole učí, a o osvojování dovedností. Navazuje na to, co již děti znají a na to, co je zajímá. Přechází od tradiční výuky podle předmětů $\mathrm{k}$ výuce podle tematických celků. Přechází od výkladu učitele, jako hlavní metody výuky, k hlavním metodám umožňujícím př́mou zkušenost, komunikaci a spolupráci.

\section{5. zásada: Možnost výběru, přiměřenost}

V obsahu i metodách výuky poskytuje S PZ takovou nabídku, která umožňuje zvládnout jak základní, tak rozšiřující učivo způsobem odpovídajícím typu inteligence a osobnosti každého žáka. Dbá o věkovou přiměřenost učiva, proporcionalitu rozumové a citové výchovy a o přiměřenost učiva vzhledem $\mathrm{k}$ individuálním možnostem žáků.

\section{6. zásada: Spoluúčast a spolupráce}

ŠPZ používá takové škály forem a metod výuky, které předpokládají spolupráci a spoluúčast dětí a využívají spolupráce $\mathrm{s}$ dalšími sociálními a odbornými partnery.

\section{7. zásada: Motivujicí hodnocení}

ŠPZ volí takové formy hodnocení, které zajišt'ují dostatek zpětné vazby a uznání všem dětem. Snaží se vytvářet nesoutěživé prostředí, vyhýbá se manipulativnímu prístupu $\mathrm{k}$ dítěti, který posi- luje jeho závislost na vnější autoritě, a rozvijî́ jeho sebedůvěru, samostatnost, iniciativu a zodpovědnost.

\section{3. pilíŕ: Otevřené partnerství}

8. zásada: Škola - model demokratického společenství

ŠPZ dělá všechno pro to, aby se co nejvíce proměňovala $z$ tradiční hierarchické instituce v komunitu organizovanou na demokratických principech, kterými jsou zejména: svoboda a odpovědnost, zachovávání pravidel a spravedlnost, spoluúčast a spolupráce.

9. zásada: Škola - kulturní a vzdělávací středisko obce ŠPZ usiluje o to, aby se $\mathrm{v}$ zájmu vytvoření a udržení demokratického charakteru své komunity zpř́stupnila veřejnosti a obci, jejich organizacím a představitelům a na základě otevřených vztahů s nimi se postupně pro své okolí stala prírozeným kulturním a vzdělávacím střediskem obce (Havlínová, Vildová, 1999, s. 33).

\section{MATEŘSKÁ ŠKOLA PODPORUJÍCÍ ZDRAVÍ (MŠPZ) SE ŘÍDÍ TĚMITO ZÁSADAMI:}

1. pilír: Péče o podmínky pro pohodu a zdraví v mateřské škole

\section{1. zásada: Celistvost zdraví}

Zdraví i nemoc u dítěte i dospělého MŠPZ chápe jako výslednici vzájemného působení organismu, psychiky, osobnosti a prostředí věcného, př́rodního i sociálního.

\section{2. zásada: Uspokojování potřeb}

Poskytuje př́ležitosti $\mathrm{k}$ uspokojování individuálních a vývojových potřeb dětí a potřeb dospělých $\mathrm{v}$ souvislosti $\mathrm{s}$ jejich činností $\mathrm{v}$ mateřské škole.

\section{3. zásada: Spontánní hra}

Vytváří prostor, čas a prostředky pro spontánní hru, která vychází z prírozených potřeb a zájmů dítěte a je proto i jeho hlavní činností v mateřské škole.

\section{4. zásada: Volný pohyb}

Ochraňuje a posiluje organismus dítěte, zejména dostatkem volného pohybu, pobytem venku, nejlépe $\mathrm{v}$ prírodě.

\section{5. zásada: Zdravá výživa}

Poskytuje stravování podle pravidel o zdraví prospěšné skladbě jídelníčku a technologii zpracování jídel a pěstuje prospěšné stravovací návyky a dovednosti ve spolupráci s rodinou. 


\section{6. zásada: Podpora sebeduvěry}

Posiluje a povzbuzuje sebedůvěru dítěte i dospělých osob v MŠ, chrání před situacemi a vlivy, které nezvládá a které je proto stresují, navozuje kladné emoční stavy a citové vztahy, vyhledává př́ležitosti ke cvičení duševní odolnosti.

\section{7. zásada: Sociální vztahy úcty a spolupráce}

Vytváří vztahy vzájemné důvěry, úcty, empatie, solidarity a spolupráce mezi všemi lidmi v mateřské škole i kolem ní.

\section{8. zásada: Pravidla a rytmy}

Stanoví a dodržuje taková pravidla pro uspořádání života a dne v MŠ, která jsou rámcová, aby jejich prostřednictvím zabezpečila rytmický řád a současně umožnila pružné rozhodování učitelky, aby zpřístupnila MŠ rodičům a podpořila komunikaci a vzájemnou informovanost rodiny a MŠ.

\section{9. zásada: Pohoda věcného prostředí}

Pečuje o svoje zdravě věcné prostředí tím, že vytvárí dynamickou nabídku takové skladby a kvality, aby bylo současně vstřícné, podnětné, estetické a hygienické.

2. pilír:: Kurikulum výchovy dětí ke zdravému způsobu života

10. zásada: První návyky, dovednosti, postoje a znalosti

MŠPZ si stanoví strukturu cílů výchovy ke zdraví, jimiž postihne její základní směr: $z$ dítěte se má stát člověk, který se bude chovat ke zdraví svému i druhých jako k nenahraditelné hodnotě - předpokladu pro plnohodnotný a smysluplný život.

\section{1. zásada: Učení prožitkem}

Volí způsoby výchovy ke zdraví takové, které samy o sobě jsou pro dítě přirozené, což $\mathrm{v}$ předškolním věku znamená, že dítě se učí prožitkem celým životem, tedy i životem v MŠ. Pokud je učíme, neučíme mluvením, ale děláním.

\section{3. pilír: Spolupráce se sociálními partnery 12. zásada: Společenství rodiny}

MŠPZ je otevřena přítomnosti rodičů ve svých prostorách a při svých činnostech, domlouvá se s nimi na společném výchovném programu dítěte, respektuje zvyklosti a prání rodiny, osobnost otce a matky.

13. zásada: Participace při řizení a ve výchově v mater̆ské škole

Praktikuje a dále rozvijí styl řízení, který je založen na participaci a kooperaci všech zúčastně- ných uvnitř MŠ. Dbá o podmínky pro subjektivní pohodu i pro objektivní zdraví učitelek a ostatních pracovníků MŠ a o odborný růst učitelek zvláště v oblasti podpory zdraví a výchovy ke zdraví.

\section{4. zásada: Zdraví podporujicí chování učitelky}

Spoléhá na odpovědnost, odborné kompetence a zdravý způsob života a chování učitelky, která je hlavním integrujícím činitelem v MŠ.

\section{5. zásada: Mateřská škola je součástí obce}

Spolupracuje s místními partnery, kteři jsou zainteresováni na programech podpory zdraví, snaží se, aby se život v MŠ prolínal s aktivitami občanů a s institucí v obci a regionu a byl otevřen vztahům mimo rámec $\mathrm{MŠ}$, aby mohlo tímto způsobem dojít $\mathrm{k}$ širší socializaci a kulturaci dítěte.

\section{6. zásada: Zdravý přechod do základní školy}

Usiluje o součinnost se základními školami v okolí, aby umožnila nestresující plynulý přechod dětí ze školy mateřské do 1 . ročníku základní školy. Je vedena přesvědčením, že má-li školní docházka znamenat pro dítě přínos, musí každé dítě na jejím startu být především mocně povzbuzováno $\mathrm{k}$ sebedůvěre ve své síly a v novou roli (Havlínová et al., 2000, s. 220).

\section{ZÁvĚR}

Evropský program ŠPZ je ve svých hlavních směrech koordinován a rozvíjen prostřednictvím setkávání a průběžné spolupráce národních koordinátorů $\mathrm{z}$ jednotlivých členských zemí. Klíčovými setkáními jsou mezinárodní konference na celoevropské úrovni, s nimi související konference několika zemí z jednoho regionu a konference národního rozsahu. Celoevropské konference se dosud konaly dvakrát. První konference $\mathrm{v}$ roce $1997 \mathrm{v}$ řecké Soluni předznamenala novou strategii ŠPZ pro 21. století zejména následujícím prohlášením: „Každé dítě a každý mladý člověk v Evropě má právo a měl by mít príležitost být vzděláván ve škole podporující zdravi“". V roce 2002 se v holandském Egmond aan Zee konala 2. mezinárodní konference programu ŠPZ. Na základě výsledků výzkumu a evaluací, které evidentně prokázaly účinnost dlouhodobě realizovaného programu, bylo jejím úkolem podnítit akční partnerskou spolupráci mezi rezorty zdravotnictví a školství v jednotlivých zemích a na nadnárodní úrovni. Cílem spolupráce nyní je, aby se výše citovaná vize 
z roku 1997 stala součástí společné strategie a předmětem akčních plánů a činnosti obou rezortů. Poslání programu ŠPZ, které nejlépe vyjadřuje prohlášení účastníků 1 . mezinárodní konference škol podporujících zdraví v Soluni, bylo zakotveno mezi cíle a úkoly akčního Národního programu dlouhodobého zlepšování stavu obyvatelstva ČR (Zdraví ve 21. stoletî). Tento program prrijala vláda ČR 30.10. 2002 k realizaci do roku 2015 (Havlínová, Herotová, Vildová, 2003).

\section{LITERATURA}

HAVLÍNOVÁ, M., VILDOVÁ, Z.: Co to je, když se řkne: Škola podporujicí zdraví, 1. vyd., Praha: SZÚ, 1999. s. 33.

HAVLÍNOVÁ, M. et al.: Kurikulum podpory zdraví v mateřské škole, 1. vyd., Praha: Portál, 2000. s. 220.

HAVLÍNOVÁ, M. et al.: Program podpory zdraví ve škole, 1. vyd., Praha: Portál, 1998. s. 275.

HAVLÍNOVÁ, M., HEROTOVÁ, T., VILDOVÁ, Z:

Škola podporujicí zdraví, nabídka rozvojověpreventivního programu pro každou školu, 1. vyd., Praha: SZÚ, 2003.

KUBRICHTOVÁ, L. et al.: Fórum výchovy ke zdraví. príručka pro učitele, 1. vyd., Praha: MŠMT ve spolupráci s VÚP v Praze a Kalokagathie, s.r.o., 2004, s. 102.

Kvetoslava Kotrbová et al. kvetoslava.kotrbova@khscb.cz 